\title{
Letters
}

\section{Greater action on climate change by physicians needed}

A landmark editorial appeared in CMAJ as part of a coordinated global call to action alongside 220 respected health journals worldwide, including Lancet, BMJ and NEJM. ${ }^{1}$ The initiative consolidates the growing voice of health care providers globally, providing education on the risks to the planet of the escalating environmental crisis of climate change combined with biodiversity loss, while advocating for the massive action emergently needed to secure a livable future for humanity.

The authoritative 2021 Intergovernmental Panel on Climate Change (IPCC) report unequivocally links climate change to human activity. ${ }^{2}$ The United Nations calls the evidence-based IPCC projections of the devastation if we fail to limit global warming a "code red for humanity." Climate change is the greatest threat to human health of our lifetimes. ${ }^{3}$

Despite this, the Canadian Medical Association's own recent "four pillars" of health care policy priorities prepared for the 2021 Canadian Federal Election did not identify environmental health as an actual pillar. ${ }^{4}$ A "climate change plan" briefly mentioning adaptation only, with no mention of mitigation, was relegated to the fine print. Likewise, most doctors recently surveyed by the Ontario Medical Association failed to recognize climate health as a priority. 5,6 We are falling dangerously short of a coordinated call to action.

The COVID-19 pandemic has highlighted our interdependences and deep vulnerabilities. However, we risk incomparably greater harm if we fail to stabilize the environment that sustains us. COVID19 has also shown us what we can accomplish when we urgently work together, while focusing public attention on trusted medical advice on a daily basis. We now have an opportunity and collective responsibility as health professionals to address the environmental crisis with the urgency and unprecedented massive scale of action needed to secure our future in the brief time remaining to act.

\section{Mili Roy MD}

Ophthalmologist, Department of Ophthalmology and Vision Sciences, University of Toronto; Canadian Association of Physicians for the Environment; Climate Reality Leader, Toronto, Ont.

- Cite as: CMAJ 2021 November 29;193: E1818. doi: 10.1503/cmaj.80289

\section{References}

1. Atwoli L, Baqui AH, Benfield T, et al. Call for emergency action to limit global temperature increases, restore biodiversity, and protect health: wealthy nations must do much more, much faster. CMAJ 2021;193:E1395-7.

2. Allan, RP, Arias, PA, Berger, S, et al. Climate change 2021: the physical science basis. Contribution of working group 1 to the sixth assessment report of the Intergovernmental Panel on Climate Change. Cambridge (UK): Cambridge University Press; 2021.

3. Costello A, Abbas M, Allen A, et al. Managing the health effects of climate change. Lancet 2009;373:1693-733.

4. Federal election 2021: reframing health. Ottawa: Canadian Medical Association; 2021. Available: https://www.cma.ca/election (accessed 2021 Sept. 17)

5. Health-care platform [virtual round table for all members]. Toronto: Ontario Medical Association; 2021 June 21.

6. Priority and Leadership Group meeting. Appendix 2: ideas review and summary. Toronto: Ontario Medical Association; 2021 Sept. 23. Available: www.oma.org/member/your-association/ governance-and-representation/priority-and -leadership-group/ (accessed 2021 Oct. 7).

Competing interests: None declared.

Content licence: This is an Open Access article distributed in accordance with the terms of the Creative Commons Attribution (CC BY-NC-ND 4.0) licence, which permits use, distribution and reproduction in any medium, provided that the original publication is properly cited, the use is noncommercial (i.e., research or educational use), and no modifications or adaptations are made. See: https://creativecommons.org/ licenses/by-nc-nd/4.0/ 